\title{
University Spaces as Agents of National Belonging: Analysing the Visual Culture of Public Universities' Campuses in India and Pakistan
}

\author{
Laraib Niaz * and Kusha Anand
}

Citation: Niaz, L.; Anand, K.

University Spaces as Agents of

National Belonging: Analysing the

Visual Culture of Public Universities' Campuses in India and Pakistan.

Educ. Sci. 2021, 11, 741. https://

doi.org/10.3390/educsci11110741

Academic Editors: Camille

Kandiko Howson and Marie Lall

Received: 23 August 2021

Accepted: 2 November 2021

Published: 16 November 2021

Publisher's Note: MDPI stays neutral with regard to jurisdictional claims in published maps and institutional affiliations.

Copyright: (C) 2021 by the authors Licensee MDPI, Basel, Switzerland. This article is an open access article distributed under the terms and conditions of the Creative Commons Attribution (CC BY) license (https:// creativecommons.org/licenses/by/ $4.0 /)$.
Institute of Education, University College London, London WC1H 0AA, UK; k.anand.14@ucl.ac.uk

* Correspondence: laraib.niaz.17@ucl.ac.uk; Tel.: +92-331-844-4426

\begin{abstract}
This article discusses the role of 'space' in Indian and Pakistani public sector universities in fostering national pride. University spaces have been highlighted, in both countries, for being used by the governments as agents fostering the national narrative yet there is limited research on how these spaces contribute to the visual culture of educational institutions and in the inculcation of nationalistic values. This article adds to the conversations regarding the fostering of national belonging and pride in universities by exploring space as a constitutive element of the visual culture of the higher education environment in India and Pakistan. In both countries, the physical spaces of public universities have become platforms for channelling student voices. This research uses two state-funded universities, from Delhi (in India) and Lahore (in Pakistan), and Lefebvre's conception of space to conduct a discourse analysis of bulletin boards, graffiti, statues, sculptures, and any other imagery found online pertaining to the campuses and analyse how it is a 'conceived' and 'perceived' aspect of the visual culture of the universities. It adds to current scholarly conversations on national pride and consciousness in India and Pakistan by showing how university spaces can potentially play an active role in promoting the state's narrative in students' or educators' everyday educational experiences.
\end{abstract}

Keywords: universities; visual culture; space; national pride; India; Pakistan

\section{Introduction}

The spaces of educational institutions are considered instrumental in influencing and propounding a country's identity and national consciousness [1]. The notions concerning national belonging in citizens of a country may not be inherently intuitive, which often results in the need to teach citizens about their membership in a country and the essence of its national narrative [2]. This is achieved particularly through the role of education as a tool for shaping political systems and fostering feelings of belonging towards the state [2]. However, this fashioning of national belonging does not happen only through the official and overt teaching in schools and higher educational institutions. It is also enabled in educational institutions through the unofficial knowledge imparted in the form of the hidden curriculum - an important aspect of which is the visual culture of the institutions [3].

The spaces of higher educational institutions, in particular, can act as symbols of unity, pride, and affection for postcolonial nations such as India and Pakistan, where the educational landscape can act as a significant tool for advancing national pride and belonging $[2,4]$. For postcolonial states having experienced the consequences of extractive institutions such as India and Pakistan, the development of national consciousness is a particularly arduous task. Both countries share a combined fractured past and an inherent proclivity towards the accentuation of differences between the 'self' and the 'other' - a distinction that forms the very basis of its violent rupture $[5,6]$. Though conceived on 
religious grounds-differences between Hindus and Muslims-India began its independent life with secularism as its focal point. In India, there is a growing consensus over the fact that religious nationalism is witnessing an exponential growth [7]. Since the onset of the right-wing government of Narendra Modi, the dominant national narrative seems to have arrogated an exceedingly nationalistic stance, that primarily concentrates on the advancement of a predominantly Hindu identity of the country. The state's attempts at promoting a nationalist Hindu narrative are not just confined to politics and the media. They are also centred around education, with the current government particularly interested in emphasising the Hindu period of rule in the subcontinent and infusing nationalistic ideals in school and university students [8]. These interventions in the educational system not only contradict the secular spirit of the country but also serve to constantly infuse a sense of national belonging and pride in the students $[9,10]$. Although visual culture remains unacknowledged and unexamined in HE in India, it constructs a powerful context of learning, shaping students' self-perceptions and worldviews.

The national narrative in neighbouring Pakistan revolves around the creation of a unified national identity-heavily intertwined with religion-that serves to inhibit all other identities along ethnic, provincial, gender, racial, and class lines [11]. Research has highlighted how the identity of a Pakistani is fostered in the curriculum not only through the subjects of Pakistan Studies and Social Studies but also through neutral subjects such as English and Urdu — all furthering a nationalistic discourse that is justified through the use of religion [11-15]. Ref. [15], in their research focusing on the voices of youth (students from both schools and universities), contended that 'The meaning of citizenship for most is linked to an uncritical notion of nationalism and loyalty to an Islamic Republic, with limited understanding of civic duties and responsibilities' (p. 105). A manifestation of this need to inculcate feelings of national belonging is how Pakistan Studies is a compulsory aspect of education from class IX up until the university level. In addition to textbooks and curricula, ref. [16] has highlighted how the daily rituals of schools, such as the singing of the national anthem and the raising of the national flag, signify a hidden curriculum that is used to foster nationalistic and patriotic fervour in students.

What remains unexplored in the existing research, in both India and Pakistan, is the influence of the spaces of educational institutions on notions of national belonging in students. This article thus explores the ways in which university campuses expand or contest narratives of national pride and belonging in higher education institutions in India and Pakistan, using Lefebvre's [17] theorisation of space and narrative-qualitative approach. Space, both physical and social, is an important component of the visual culture of educational institutions and helps shape students' interactions with their peers and their teachers, as well as their perspectives and approaches towards the processes of everyday learning [18]. In both countries, the spaces of public universities, particularly in Delhi and Lahore, have become pedagogic media for active student voices and resistance in the form of the citizenship amendment protests in India and the student solidarity marches in Pakistan. Our aim is not to compare the two countries, but rather to use the contrast of contexts [19] approach to understand how the public university spaces are 'conceived' as aspects of furthering their national narratives and how this visual culture can potentially be 'perceived'.

The article is structured as follows. First, we discuss the current literature on educational spaces and their visual culture, considering Lefebvre's [17] theorisation of space, in particular, as an interplay between conceived, perceived, and lived spaces, in order to create a conceptual link between space and the visual culture. We then introduce the setting in which the study took place and outline key methodological considerations. The findings, which are structured around the analysis of the 'conceived' and the 'perceived' [17], are presented next. The subsequent discussion draws upon the findings to theorise three factors determining the extent to which the university spaces act as agents for fostering national belonging and pride. 


\section{Educational Spaces and Visual Culture}

Space is progressively seen as an active element of social life; it is "... socially produced and simultaneously socially producing; concurrently material and imaginary; intimately connected to embodiment; and irreducibly political" [20]. In his seminal work, Lefebvre [17] proposes the presence of multiple, overlapping spaces. First, space is produced by purposeful planning and design [21] to represent the values and goals of the government [20]. Next, space is defined by individual insights, connections, and actions with the built environment [20]. Space is essential to student learning, as it constructs the logic of "belonging to an intellectual home", one that is designed by the organisation and the "staff members as its permanent occupiers" ([22]; p. 127). Nevertheless, the impact of space on its populations is never neutral [20,23]: the structure, design, and architecture of physical space are essentially political and performative [24,25].

In addition, space mediates student communication with their peers and their teachers, as well as their viewpoints and approaches towards the process of learning and what is being learned. [22] advocates for a balance between the malleability of space to the needs and wishes of its inhabitants and the preservation of 'expectations that a university is traditionally something special and different' (p. 128). The relationship between the physical dimensions of the curricular space and the imaginary spaces fostering creativity and innovative learning has received scholarly interest [26], as has the heterotopic curricular practices that encourage critical and imaginative thinking [27]. Perhaps the most radical example of such a university space is the iconic Building 20 at the Massachusetts Institute of Technology (MIT) (see Figure 1) [23]. With MIT placing little to no interest in managing the building, its inhabitants were given the freedom to repurpose, redesign and use the building in ways that fostered creativity and independence of thought that is pivotal to the ground-breaking research conducted in the university [28].

Space is particularly recognised in education literature as a dynamic factor establishing the tacit features and practices of education that shape everyday student experience and learning [29-31]. In particular, there has been a growing understanding around how observable and tactile information, linked to visual spaces, forms an important component of everyday educational experiences [32-34].

Scholars [35-37] have outlined how what is called the 'visual but hidden' conundrum, which focuses on the multi-faceted nature of everyday experiences in schools and universities, and answered questions such as 'what is visible?' and 'what is noticed?'. In this sense, the everyday visual culture of universities contributes, in some ways to the everyday visual experiences in schools and universities. Before going further into the components of visual culture, it is important to define the term. For the purpose of this article, we will use the definition by [36]:

'the ready-made standardised visual scheme handed down by previous generations of teachers and authorities as an unquestioned and unquestionable guide to all observable events, rituals, situations, objects, materials, spaces and behaviours which normally occur within everyday schooling.'

Prosser [37] has outlined a number of aspects of visual culture that are essential elements of school and university spaces, such as the architecture (buildings, classrooms, laboratories, etc.), non-teaching spaces (playgrounds, cafeterias, assembly rooms, changing rooms), cultural inventory (photographic inventory, artefacts, and proxemics), teacher and pupil spaces (staff rooms, student dormitories), and finally aides to teaching and learning (notice boards, wall art, posters). Additionally, this visual culture can also be shaped by students themselves [38,39], through the use of space as a platform for student expressions. It is also important to note how the above-mentioned factors are overlapping in nature. Moreover, considering educators' and students' capacity to reflect, learn, and interpret, every educational institution will have its own unique visual culture and a unique way in which space is conceived and perceived. 
What is missing from the literature is the understanding of how this serves as a form of visual culture (through the built environment, photographic culture, and so on) and how it can be implicitly and explicitly used as a form of furthering a country's national narrative.

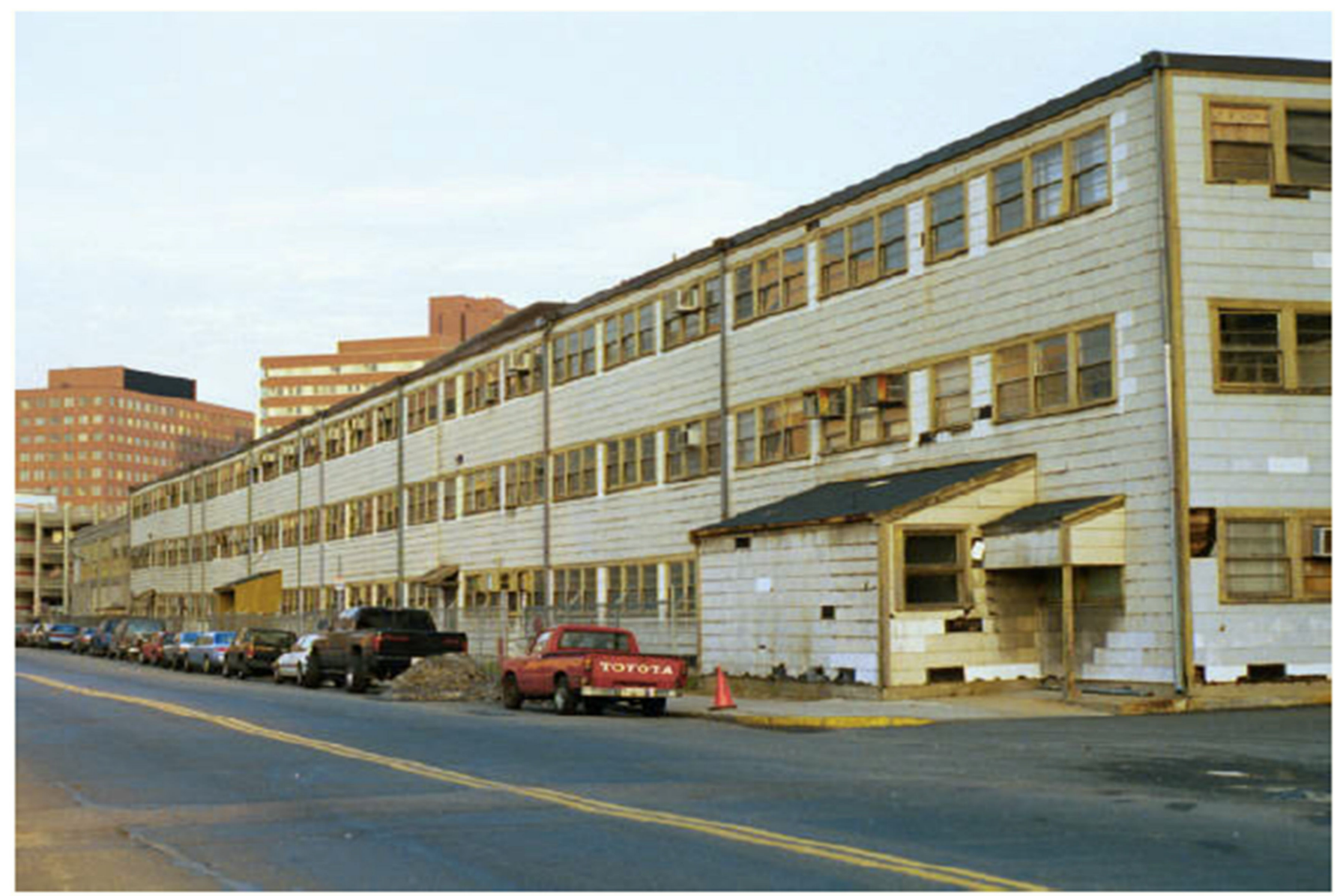

Figure 1. Building 20 at MIT. MIT gives its inhabitants freedom to repurpose, redesign, and use the building in ways to foster creativity and independence of thought (Source: DGCOregon.com (https:/ /jjcoregon.com/news/2012/06/19 /building-20-what-made-it-so-special-and-why-it-will-probably-never-exist-again/ last-accessed 10 September 2021)).

\section{Methodology}

To explore the ways in which the physical and social spaces of public universities in Delhi and Lahore foster national belonging in students, we used the discourse analysis approach and incorporated Lefebvre's [17] theorisation of space, in particular, as an interplay between conceived, perceived, and lived spaces. Discourses are drawn from messages written on the university's walls, as well other images, paintings, murals, or statues present in the university architecture. Here, we do not make assumptions about how students will react to the visual culture. Our focus is rather on space and how it could potentially influence students' notions around national pride and belonging.

Research sites and rationale: We chose a purposive sample of four public universities, from Delhi and Lahore (the biggest public universities in both cities). The intention is not to generalise the analysis to the entire higher education system of both countries, but to give a reflection of the public university sphere by choosing the largest state-funded universities operating in both cities. These are also the universities that have been linked to student politics in the past, which we believe provides an interesting link with the fostering of national belonging in the students. We provide the rationale for selecting the four institutions below. 
Jawaharlal Nehru University (JNU) and Jamia Millia Islamia University (JMIU), in Delhi: JNU was established in 1969 and named after Jawaharlal Nehru, India's first Prime Minister. The first vice-chancellor, Gopalaswami Parthasarathy, set out JNU's radical mission of pioneering interdisciplinary academic centres designed to solve issues intrinsic to Indian society: poverty, development, and social division (https:/ / theconversation.com/jnuviolence-indian-universitys-radical-history-has-long-scared-countrys-rulers-129488, accessed on 10 September 2021). Jamia Millia Islamia was founded as an act of resistance against the British occupation of India. As part of his Non-Cooperation Movement, Mahatma Gandhi had called for the boycott of all educational institutions supported or run by the colonial regime. On 12 October 1920, Gandhi visited Aligarh Muslim University, calling for a boycott of the British-funded education system. Responding to his call, a group of young teachers and students came forward to form the National Muslim University, later known as the Jamia Millia Islamia. Jamia's first batch of students-young men-were ready to compromise their futures for the sake of being enrolled at a university deliberately formed to challenge oppressors. It moved to its current location in Okhla in 1935. It was given the deemed status by the University Grants Commission in 1962 (https:/ / www.firstpost.com/india/in-jamia-students-anti-caa-protests-areechoes-of-the-universitys-challenge-to-british-occupation-of-india-8034031.html, accessed on 10 September 2021). The protests by JNU and Jamia students now are somewhat reminiscent of the resistance with which these institutions were founded and established. The campuses of Jawaharlal Nehru University and Jamia Millia Islamia are two of the most vibrant campuses in the country, with a culture of open debates and intellectual discourse. The wall writings in the universities give a running commentary on the state of affairs in India and the world, ranging from the issue of privatisation and so-called multinational onslaught to issues concerning gender divide, corruption, and terrorism.

University of the Punjab and Government College University Lahore: Punjab University (PU) was established in Lahore in 1882 by the British colonial authorities. It possesses the title of the first higher education institution established in a Muslim majority area and is therefore considered an emblem of the shared history of the subcontinent. It hosts a separate department for History and Pakistan Studies and has been the bedrock of student politics and activism since Pakistan's inception, with [40] describing how 'With respect to targeted campus violence, Punjab University-Pakistan's oldest university-forms the primary site for ideological conservatism'. In particular, the physical space of the university has been the source of reverence, debate, and controversies. The architecture was at the forefront of a sectarian conflict, for instance, between members of the Islami Jamiat-e-eTalaba and some Shi'a students, who were demanding separate 'territorial protections-up to and including a separate local mosque' ([41]; p. 573). Government College University Lahore (GCU) was one of the oldest colleges established in pre-partition Pakistan (formed in 1864 - even before the establishment of the university of the Punjab—it was afforded the status of a university in 2002.). GCU holds a significant status in the history of the nation, having housed symbolic and influential figures of the freedom movement such as Dr Allama Muhammad Iqbal (politician, philosopher, and accredited national poet of Pakistan) and Ahmed Shah Patras Bokhari (a diplomat, writer, and broadcaster who was appointed as the first parliament representative of Pakistan to the United Nations.). GCU, much like PU, has been the subject of considerable interventions by the state, such as terminating contracts of professors in response to them voicing their political views [40], making it an important case study for understanding the visual culture of university spaces in fostering national belonging.

Data collection: As a result of the restrictions imposed due to COVID-19, we were unable to physically visit the campuses and collect primary data for this research. We therefore conducted secondary research using online materials (from 2014 to the present and related to any aspects of the nations) that we could find on the internet. The data were collected from the various online resources in a series of steps (see Table 1 for detail). Our first point of data collection were the official university websites, followed by their 
policy documents, news articles, and blog posts in the media and materials found on social media sites-Twitter and Facebook. This process then involved moving from more official and formal to more unofficial and informal visual content over the internet. The content on social media websites such as Twitter and Facebook highlighted the importance of social media in university imagery. Importantly, these images were mostly posted by the students, with the individual universities not having an official social media presence. We also want to add how, through the data collection process, we also expanded our research to incorporate artefacts such as statues and flags on the university campuses, and the data from the news articles, university websites, and policy documents also allowed us to incorporate any official statements by the state and individual universities with respect to aspects of campus spaces. Given below are details of the number of images collected.

Table 1. Data Sources.

\begin{tabular}{|c|c|c|c|c|}
\hline \multirow[b]{2}{*}{ Source of Data } & \multicolumn{4}{|c|}{ Images Collected in Numbers } \\
\hline & JNU & JMIU & PU & GCU \\
\hline $\begin{array}{c}\text { Step 1: Official } \\
\text { University } \\
\text { Websites }\end{array}$ & 12 & 14 & 10 & 16 \\
\hline $\begin{array}{c}\text { Step 2: } \\
\text { University } \\
\text { Policy } \\
\text { Documents }\end{array}$ & 17 & 10 & 15 & 8 \\
\hline $\begin{array}{c}\text { Step 3: News } \\
\text { Articles and } \\
\text { Blog Posts }\end{array}$ & 20 & 15 & 18 & 12 \\
\hline $\begin{array}{l}\text { Step 4: Social } \\
\text { Media Presence }\end{array}$ & 10 & 12 & 11 & 14 \\
\hline
\end{tabular}

Data analysis and coding: We used the data analysis framework outlined by Lecompte (2000) by conducting the analysis in a series of steps. The data were qualitatively analysed. The number of graffiti messages was counted. The inscriptions were recorded by the researchers and were then transcribed for further analysis. The thematic analysis is a flexible qualitative method used to analyse data (i.e., graffiti) by collecting similar thematic codes to relevant groups of meaning [42]. The first step involved "tidying up" the data and selecting images that were only related to notions of national pride and belonging. This required a process of open coding where all images were coded. Axial coding was the next stage, where we reviewed the initial open codes to see which ones were being most frequently used to determine themes and patterns in the data. We then conducted a process of thematic analysis where, from the 42 images shortlisted (both from India and Pakistan), three themes were developed (detailed in the Findings section).

Subsequently, the themes were revisited and reviewed so as to safeguard that the whole data were relevant for the formulated themes. Thematic coding permits the researchers to review the whole data by recognising their supremely important meaning or what the data are trying to say or tell [43]. This method, as has been claimed ([42], p. 5), can 'potentially provide a rich and detailed, yet complex account of data' and patterns, and made the examination of the data easier. The thematic analysis [44] is based on Critical Discourse Analysis [45], as there is an interaction between the text, discursive practices, and the social context [46]. Therefore, it is valuable and essential to acknowledge the importance of graffiti discourse as a product of human linguistic expression besides the nature and impact of the message being conveyed. Ref. [47] added that the significance of graffiti discourse should be recognised as a mode of communication informing about main social issues and problems. 
Authors' positionalities: We also want to take note of our positionalities and how that further helped in conducting the research, since we have visited these universities in the past and are well aware of the educational fabric of the cities of Delhi and Lahore. The national pride and belongingness on university campuses are not objectively laid out in order to be understood in a passive manner by the reader. Rather, in this article, the identities of the authors are important in the analysis of the themes reviewed. Each author had the responsibility of reviewing themes and collecting data on each country's context-the first author on Pakistan, the second on India. In each case, the author is a holder of the respective national identity and has been a consumer of the educational discourses of the respective countries whose themes are being reported.

\section{Key Findings}

The findings point towards a number of aspects of the relationship between visual culture, university spaces, and national belonging and pride. Space is deliberately used to symbolically orientate the university and to reflect organisational or political values and ideals; space also provides a medium for the contextualisation of students' resistance and voices. The findings below are structured around three mutually related aspects of space through which student experience is shaped-symbolic artefacts at the university premises, walls of nationalistic and patriotic heroes, and graffiti-the space for student voices. Within each sub-section, we explore the conceived, and the possibly perceived of the lived spaces and how they constitute the visual culture of university spaces, which in turn can potentially shape the student perceptions and experiences of the campuses in Delhi and Lahore.

\subsection{Symbolic Artefacts at the University Premises}

Both India and Pakistan, irrespective of their individual differences, have been known to engage in ritualistic activities to advance their national identities through symbolic representations (artefacts) of the group: the national flag, the army, the anthem, are all symbols that conjure up the image of the nation and ideas of national identity. Indeed, according to [48], one of the most important functions of symbolic artefacts is their ability to objectify relations between individuals and groups and therefore to reify questions of identity. Symbolic forms can stand for 'a wide range of meanings, agitate emotions, [and] spur them into action' ([44]; p. ix). In the light of contemporary theories of nationalism, this section considers how nations are social constructs where symbolic artefacts actively participate in this process of construction; it analyses the sets of meanings and values that have been used in making claims about national identity [49].

Though the flag as an element of communication is present in public ceremonies, sports contests, and competitions, and it is frequently displayed in times of trouble as well as on holidays and patriotic occasions [50] - we found its symbolic value more oriented towards fostering national pride through the official statements of the state and the universities in both countries. The national flags display reflects the university's culture as well as how national identity and values are cultivated, and serves as a form of visual culture. The national flags and statues, as a representational university space for collective activity are appropriate for the respective governments to promote a collective nationalistic identity and pride and rehearse notions oof good citizenship.

In India, since 2016, India's Hindu nationalist BJP government has ordered major universities to prominently display the country's national flag. In both Jawaharlal Nehru University (JNU) and Jamia Milia Islamia (JMI), the university websites included pictures of the campus with the Indian flag prominently displayed. The universities were ordered to install flag masts, 207 feet tall—about the same height as the Statue of Liberty-to hoist the nation's tricolour flag (see Figure 2 below) [50,51]. To hoist the flag at precisely 200 feet would, according to state officials, further deepen their sense of patriotism (The decision came in the midst of a raging row over the arrest of JNU Students Union president Kanhaiya Kumar on sedition charges, for being present at an event on the campus where 
anti-India slogans were raised. Hence, the conceived impact of the existence of the flag (as a symbolic gesture and by the government itself) would be to influence feelings of nationalism in students. The chairman of the Centre for Media Studies at JNU said that the government's decision was aimed at 'instilling nationalism and pride' in students and was one of 12 resolutions passed by the vice-chancellors [49].

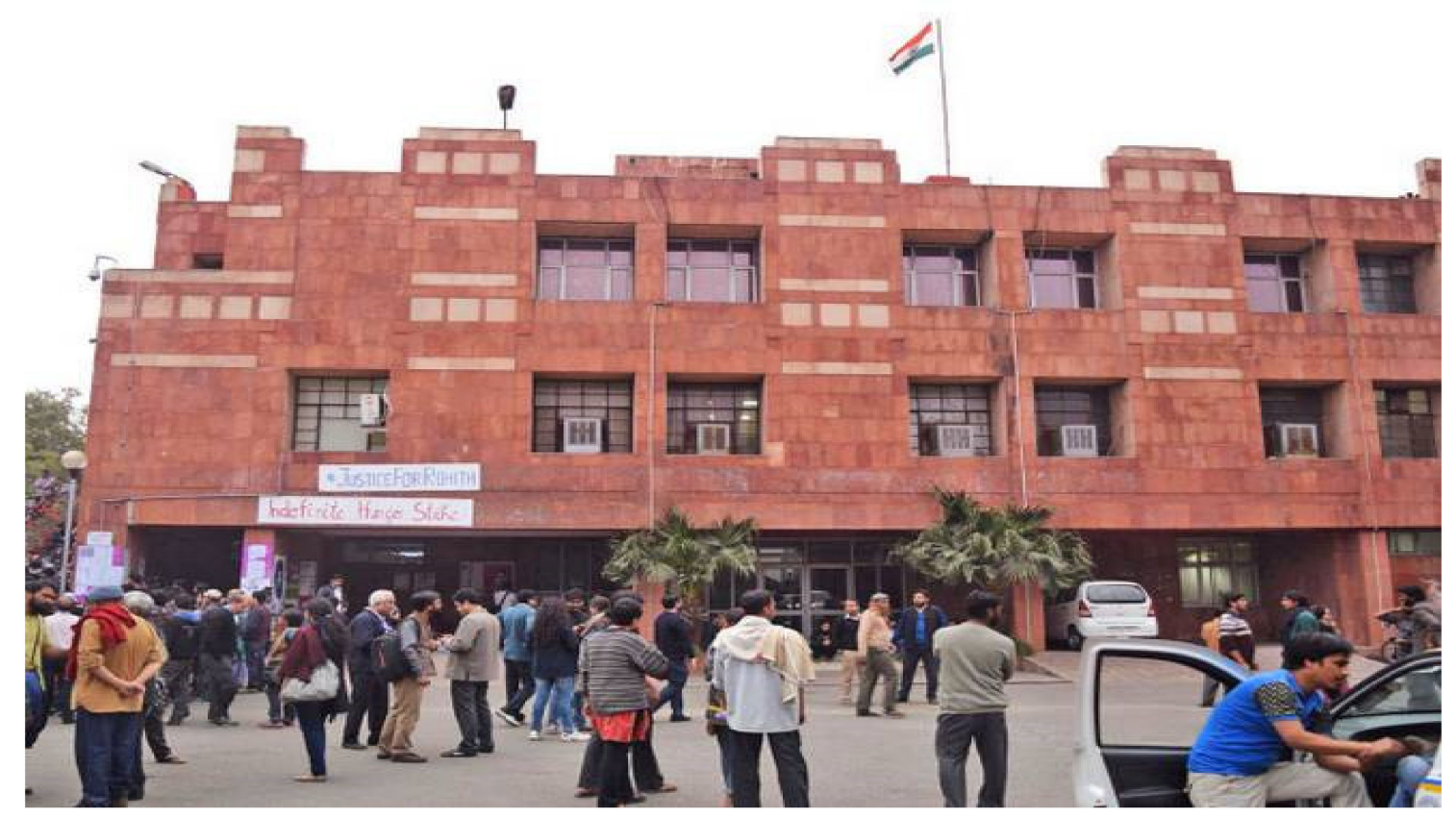

Figure 2. The national flag waving atop the Jawaharlal Nehru University (JNU) (Source: The Hindu (https: / /www.thehindu. com/news/ cities/Delhi/15-years-before-hrd-diktat-jnu-hoisted-flag/article8259680.ece, accessed on 10 September 2021)).

In addition, in 2017, Jagadesh Kumar (the vice-chancellor) reportedly called for an army tank to be installed on campus to inspire nationalism - here, again, a symbol was used to contribute to the everyday visual culture of universities, to inspire the outcome of awakening a sense of national pride, though these actions have challenged JNU's radicalism and independence-it is important to be cognisant of how students might critically engage with the installation of such artefacts. The conceived aspect of the visual components of the university campuses may not necessarily translate into the one 'perceived' by the students. A case in point, the decision to institute the flag and the tank resulted in student protests at Jawaharlal Nehru University (JNU)—signifying a divergence between the 'conceived' and the 'perceived' and the increasing role of students' positionalities and orientations.

In Pakistan, the national flag is a permanent fixture in public as well as private universities. The famous senate house located at the centre of the Punjab University (PU) is home to the national flag of Pakistan. In Government College University Lahore (GCU), the national flag can be seen positioned near the clock tower, as identified through visual imagery found on their website. Additionally, the hoisting of national flags is one of the rituals that both centrally funded universities and private universities adhere to, during the celebration of Independence Day and other days of national interest at both PU and GCU. Even after the advent of COVID-19, flag hoisting ceremonies at both PU and GCU on 14th August 2020 have taken place, with the event at GCU attended by the Governor of Punjab. While addressing the ceremony at PU, a professor stated how the university was thankful to national icons such as the father of the nation Muhammad Ali Jinnah (founder of Pakistan) and how this ceremony would help in fostering pride in students for their country [52]. Here, again, both the state apparatus and the university administration clearly indicated their stance on the symbolic value of the flag. The 'conceived' aspect of the flag, much like the case of India, was oriented towards awakening senses of national pride and belonging. The symbolism of the flag can also be discerned from the fact that 
students in PU were asked to paint the national flag to commemorate the Independence Day of Pakistan and for Pakistan Day (a national holiday commemorating the resolution of Pakistan on 23 March 1940) parade in 2018, an event with the eulogisation of national heroes (as seen in Figure 3 below). This nationalistic discourse that focused heavily on instilling patriotism in students and fostering pride in the national figures of the past was complemented by the visual aid provided by the presence of the flag and the symbolic value attached to it.

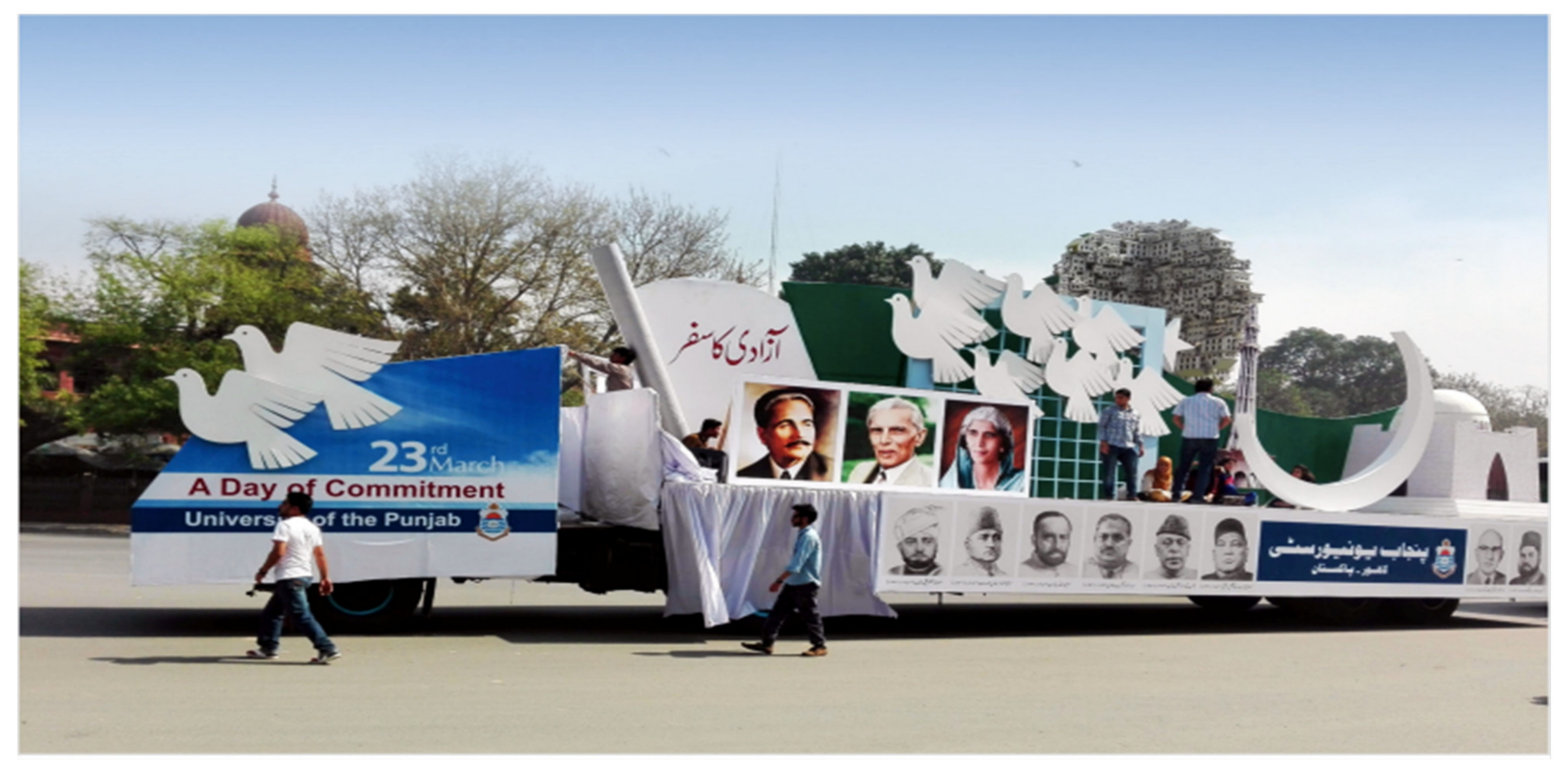

Figure 3. Retrieved from PU Factbook 2018, reflecting a celebration of Pakistan Day with pictures of the national figures Muhammad Ali Jinnah, Allama Iqbal, Fatima Jinnah, and many others, with the words azadi ka safar (road to freedom) written above the pictures (Source: PU.edu.pk (http:/ / pu.edu.pk/downloads/Fact-Book-2018.pdf, accessed on 10 September 2021)).

Saigol [16], in her research on the making of the Pakistani citizen through everyday schooling, has previously noted how the hoisting of the Pakistani flag contributes to the daily regimentation of strict rituals that can be linked to the formation of the Pakistani citizen.

There is a lack of similar research for higher education institutions and a particular lack of research on the symbolism of the national flag itself. Since the national flag is a permanent fixture of everyday campus life (now both in the universities examined in India and Pakistan), it does contribute to the everyday life of students and could foster a sense of belonging to the Indian and Pakistani state through its visual presence. However, unlike what happened in India, there were no resulting student movements and protests in response to the institution of flags in Pakistan. This might indicate a convergence of the 'conceived' and 'perceived' aspect of visual culture for the students in Pakistan, or perhaps a lack of reflection on the freedom of choice associated with the existence of nationalistic components in the everyday visual culture of the universities.

What also compliments the day-to-day learning of the students are various statues and other artefacts present within the campus spaces, particularly in India. The need to install and unveil a statue of Swami Vivekananda at the Jawaharlal Nehru University (JNU) campus came from such symbolics of power and pride [49]. Narendra Modi has said how he hopes that 'the statue instils courage and compassion that Swami Vivekananda wanted to see in everyone. When we were oppressed during colonialism, Swami Vivekananda went to Michigan University in the earlier part of the last century \& had said that even though this century is yours, next century will belong to India. It is our responsibility to realise this statement vision.' During the online event held in November 2020 ([53]; 
para. 1), Modi outlined how the purpose of the statue was to inspire 'a vision of divinity', further elaborating on the need for JNU students to derive courage and compassion from Swami Vivekananda (an Indian Hindu monk), in addition to ideas of service to the nation and love for humanity [54]. He mentioned how the names of the hostels in JNU—Ganga, Yamuna, Sabarmati, Jhelum, Sutlej (rivers in India), and so on-were symbols of national unity and integration [55]. -They were 'conceived' as aspects contributing to the visual culture of the universities. JNU's vice-chancellor, Jagadesh Kumar, shared that the statue is giving the campus a "pleasing look", as Swami Vivekananda has contributed to nation building and it is important to instil nationalist fervour in students [54] (however, the installation of the statue was seen as a prominent symbol of the saffronisation of the campus. In the campaign against it, the statue was vandalised a couple of times. An FIR was filed against unknown perpetrators. https://indianexpress.com/article/explained/ explained-jnu-vivekananda-statue-pm-modi-7049354/, accessed on 10 September 2021). The statements clarify the way in which space was 'conceived', as contended by [5], in a manner that is physical, yet also social and imaginary-in this case, imaginary in terms of its perceived connection with the freedom movement of India and in instilling a sense of national pride.

In Lahore, Punjab University has a statue of Alfred Woolner, who was the first vicechancellor of the university, which is the last remaining statue of a colonial figure present on campus. Other symbolic artefacts on campus consist of Holy Islamic sayings that are written on nameplates and attached to trees around the campus. Since the national narrative of Pakistan focuses so heavily on a unified Islamic identity, the visual symbolism of these sayings extends to notions of nationalism as well. Similarly, in GCU, Holy Islamic sayings on name plates and other religious artefacts, such as paintings of Holy Islamic sayings, are plastered across the walls and form a part of the everyday visual culture of the campus. The formal architecture of the campuses also incorporates religion through the provision of prayer rooms and mosques. However, by heavily relying on one aspect of identity, the university space effectively fosters the construction of the 'self' and the 'other' along religious lines. Much research in Pakistan has focused on the construction of the self and other in textbooks and curricula (see, for more detail, [11-13]), yet hardly any research has investigated the impact of visual representation in school and university campuses that might foster a construction and subsequent negative attitudes towards the external and the 'other'. How students perceive these symbols inside the university would depend on a variety of factors, yet the abundance of Islamic symbols in the visual atmosphere of the campuses does reflect the religious identity of Pakistan, which is heavily intertwined with the nation.

Space, in this sense, physical, but also social (particularly through the presence of the mosque in PU and GCU and the Vivekananda statue at the entrance of JNU and flags in all four universities) and imaginary, as the everyday experiences of students and the heavy involvement of religion and patriotism might potentially foster a sense of national belonging.

\subsection{Furthering Nationalism and Patriotism through Walls of Heroes}

Another aspect of 'space' influencing the paradigms of national identities and the replacement of ideological foundations in India and Pakistan is the appropriation of the pantheon of father figures and national icons. The founding fathers, who are the ideological figures of national inspiration, are essential elements for the birth of both nations. These national icons are indeed important, as they symbolically embody the values and ideals of the nation [16].

In Delhi, in a bid to pay a tribute to the Indian army, the Ministry of Human Resource Development (MHRD) (now renamed as the Ministry of Education) decided to construct a wall of heroes in all the universities and institutes across the country [55]. Additionally, the MHRD launched a 'Vidya, Veerta Abhiyan' (Knowledge and Warrior Campaign) to inspire varsities to show portraits of soldiers decorated with the Param Vir Chakra (India's highest 
military decoration, awarded for displaying acts of valour during wartime), the country's highest military decorations, on university campuses such as Jawaharlal Nehru University (JNU) and Jamia Millia Islamia (JMI). The MHRD itself emphasised how this change had been implemented to inculcate feelings of nationalism and national belonging in students at JNU and JMI-essentially forging a link between these walls and nationalism. In 2016, the JNU's vice-chancellor, Jagadesh Kumar, had stated that portraits of martyrs and tanks used in wars should be put on display on the campus to instil a sense of nationalism and patriotism among students [55]. In 2017, Kumar mounted a Wall of Heroes to 21 decorated soldiers, making JNU the first university to comply with the MHRD's 'Vidya Veerta Abhiyan'. Kumar wiped JNU's magnificent mural art and posters [56,57]. The images we collected of these walls illustrate patriotic martyrdom and pride by demonstrating a symbolic event in the lives of nationalist heroes. In this sense, these images become an important component of the visual culture of everyday campus life.

The walls of heroes are not just exclusive to Delhi; even in Lahore, public universities are filled with portraits and pictures of national figures deemed important to the freedom struggle of the country. In both Punjab University (PU) and Government College University (GCU), the entrance of the universities and a number of their buildings (particularly the senate house in PU) houses portraits of national icons such as Muhammad Ali Jinnah, Sir Syed Ahmed Khan (Islamic reformer, educationist known for his contributions to the welfare of Muslims in the subcontinent during British rule) and Allama Muhammad Iqbal (See for instance Figure 4).

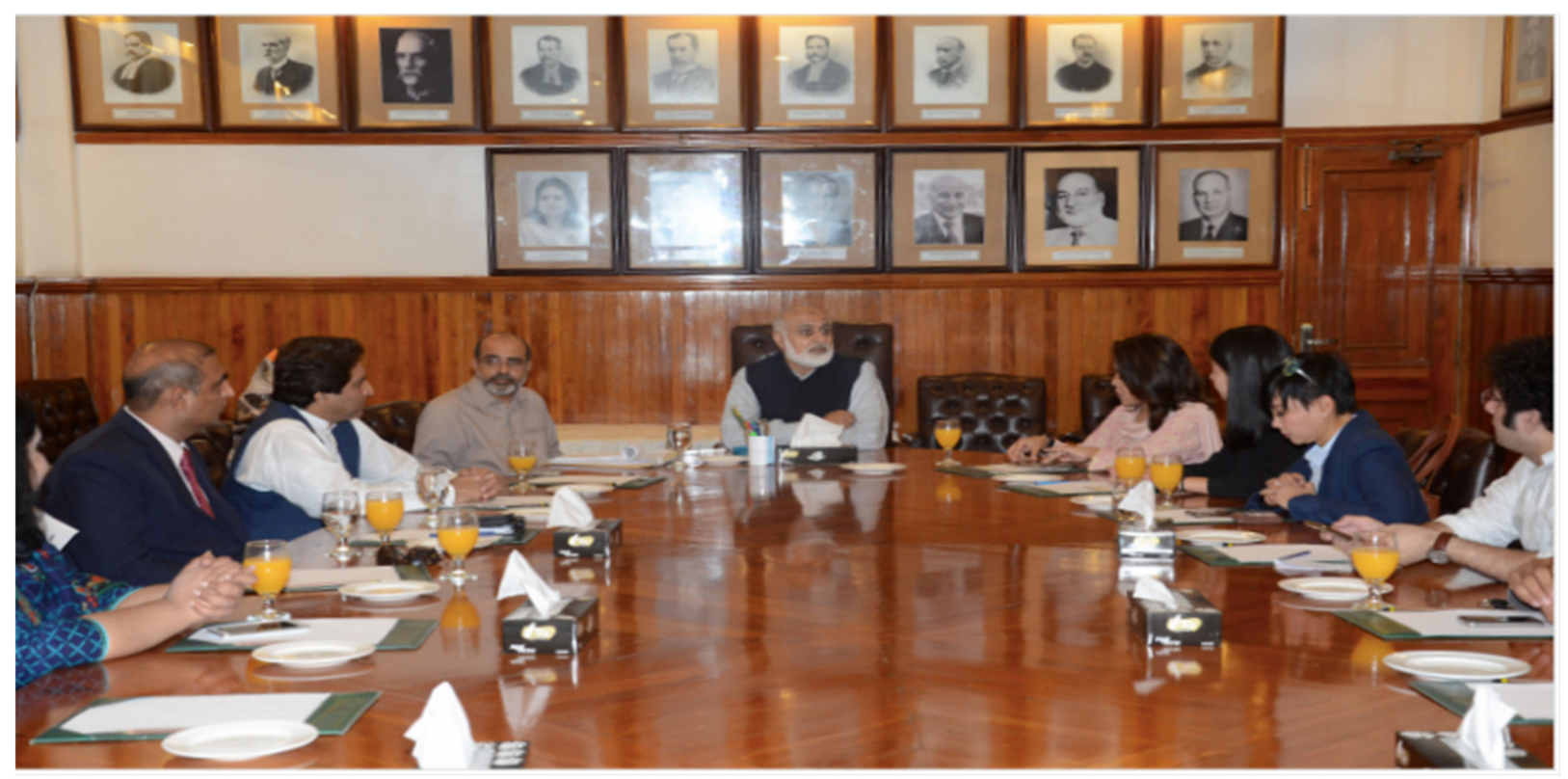

Figure 4. Here, in the board room, pictures of national figures of Pakistan (mostly men), such as Muhammad Ali Jinnah and Allama Muhammad Iqbal, can be seen plastered over the walls. Retrieved from Punjab University (Pakistan) (Source: PU.edu.pk (http:/ / pu.edu.pk/ downloads/Fact-Book-2018.pdf, accessed on 10 September 2021)).

The reverence afforded to Allama Muhammad Iqbal and Muhammad Ali Jinnah can be perceived through the official naming of the two campuses in their honour (the old campus is now named after Iqbal and the new campus after Jinnah). The names of both figures are thus plastered outside the gates of the campuses, becoming a part of the visual component of everyday university life. This is a reflection of the pre-eminence of Iqbal and Jinnah in the societal fabric of the country, where they are considered pioneers of the freedom movement and are eulogised and commemorated through national holidays.

It is interesting to see how the shared past of the two countries in terms of their freedom movements is given a similar, if not analogous, level of reverence in the university spaces examined. Here, we can see how the visual images of the national figures are 
'conceived' as important aspects for notions of national belonging and identity through the visual culture of the institutions in both countries. What can also be delineated is the role played by the university spaces-using the physical spaces of the walls as a form of social and discursive space, that furthers the notion of what Benedict Anderson terms the imagined community, by utilising emblems of the past as visual reminders in everyday life. In both India and Pakistan, even after more than 75 years of independence, the violent and fractured past and the construction of the 'self' and the 'other' (with India the enemy other for Pakistan and vice versa) is a dominant narrative, with military and national figures symbolising not just feelings of belongingness for the 'self' but also a reminder of differences with the 'other'. However, how students 'perceive' this visual culture in their daily educational life might vary, and the exact impact can be determined through a more ethnographic approach to their attitudes.

\subsection{Political Graffiti and Art on the Walls of Universities-The Space for Student Voices and Resistance}

'Walls are a marvel, don't you think? I have always paid a great of attention to what happens on wall. When I was young, I often even copied graffiti.' [58].

Graffiti and wall art is a form of visual (sub-)culture that stands for any mark left on the wall, formally or not, by a person, consisting of anything ranging from a name, a logo, or a casual design to a signature. Wall art is thoughtful and more organised than graffiti, and the artist is aware of the political implications of the imprint that he or she leaves on the wall [59]. In this section, we discuss how spaces such as graffiti on the walls of the universities' campuses in Delhi and Lahore echo the views, aspirations, and motivations of the student community on their university campuses and how these walls become a projection of their collective and individual voice of resistance and protest-forming an important aspect of the visual culture of the universities. Graffiti has not historically been a large phenomenon in India and Pakistan. Nonetheless, it is beginning to make a mark on the walls and buildings of metropolises such as Delhi, Mumbai, and Bangalore and the cities of Lahore and Karachi, in Pakistan. In Delhi and Lahore, painting on walls can provide students with a sense of anonymity along with visibility.

The campus of Jawaharlal Nehru University (JNU) has one of the oldest graffiti backgrounds. That is not surprising, since JNU has one of the most active university environments in the country, with a culture of open debates and intellectual discourse [54,60]. The graffiti on the walls of JNU symbolise the voice of dissent on campus. While they do not have separate tags, signatures, or markers, they are custom-made by different political parties and their students' wings, and they thus necessarily have the name of the political party highlighted (see Figure 5). The graffiti is intertwined into the fabric of student life and has inserted, imposed, and inflicted itself on the visual culture of the campus, undercutting authoritarian attempts, if any, to establish a sort of homogeneity or normativity in the architectural landscape of JNU [59].

In 2019, the vice-chancellor of JNU ordered the removal of the wall posters pasted all over the campus [61]. JNU's administration started removing all the posters and graffiti from the university's walls as part of the Swachh (clean) JNU initiative, under the Delhi Prevention of Defacement of Property Act, 2007. This resulted in a significant backlash from the faculty, alumni, and students. In response to the order, the president of the JNU's student union, N. Sai Balaji, wrote an open letter expressing his anguish while highlighting the significance of walls-a space that enables students to express dissent through words and art ([60], para. 2). The emphasis on dissent highlights how these spaces were both 'conceived' and 'perceived' by the students as an active form of resistance to state narratives. 


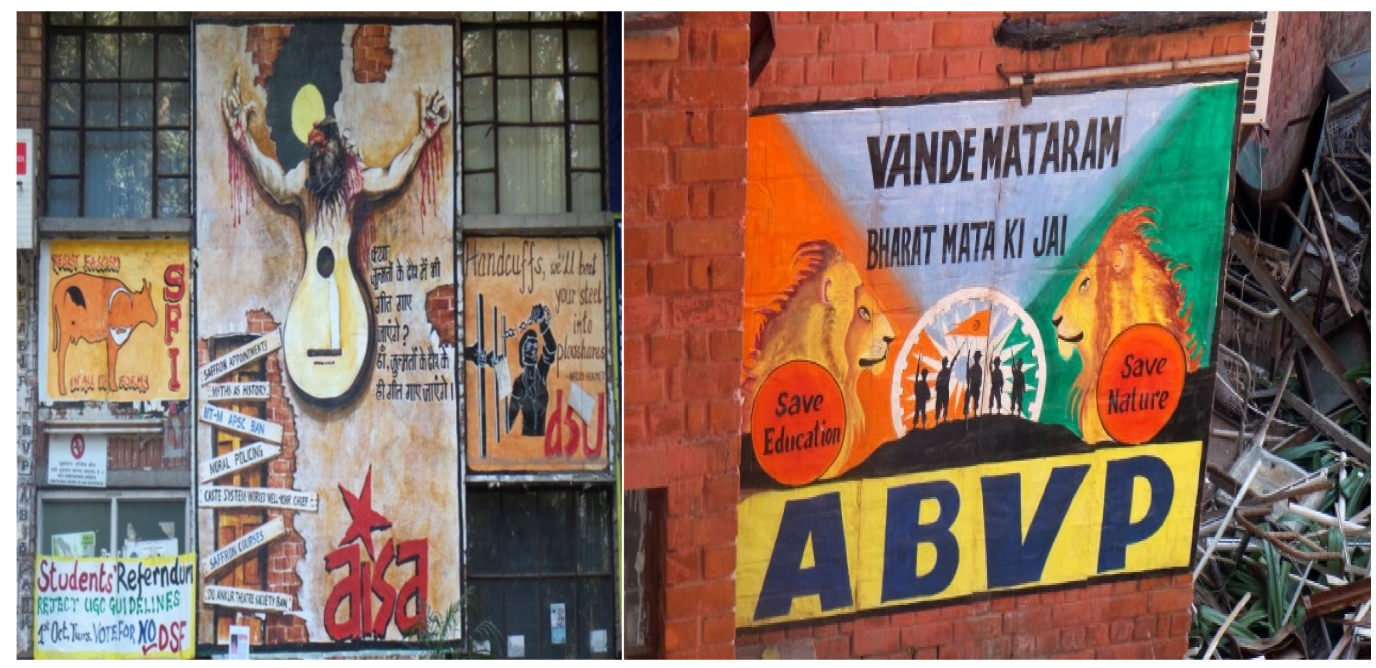

Figure 5. Graffiti inside the JNU campus shows All India Students' Association (AISA) and Students' Federation of India's (Left student group) versus Akhil Bharatiya Vidyarthi Parishad's (ABVP) (RSS-affiliated organisation). The second picture, by ABVP, reads: 'I praised to motherland, Mother. Victory for Mother India' (Source: [57]).

Similarly, students of Jamia Millia Islamia University, in Delhi, turned the campus' stonework walls into a canvas of discontent. Inside the campus, murals draw parallels between Prime Minister Narendra Modi and his Hindu nationalist party's lotus symbol and Adolf Hitler and the Nazi swastika. The graffiti and slogans on the walls of the university were a spontaneous response to the law pushed through Parliament by the Modi government that offers naturalisation for Hindu, Christian, and other migrants who fled religious persecution in Bangladesh, Pakistan, and Afghanistan. The law does not extend to Muslims. Students claimed that if the government would not hear their voices, the walls would talk [62] (see Figures 6 and 7, below). At Jamia Islamia University, artist Gargi Chandola discovered through social media that artists were gathering at the Jamia Millia Islamia university campus in New Delhi following a brutal police crackdown on students protesting the new citizenship (see Figures 6 and 7, below). She created art and called this the 'creative collective conscience' flowing across the artist community and the wider public. She said: that 'Art has the power to invoke the silent majority to come to join the movement, as we are seeing with these protests' ([62], para. 3). This shows a divergence in the 'conceived' and 'perceived' dimensions of the physical and social space of the campuses. Where the government and school administrations used the space as a vehicle for fostering pride, the students perceived it as an element for showing resistance to the government's narrative.

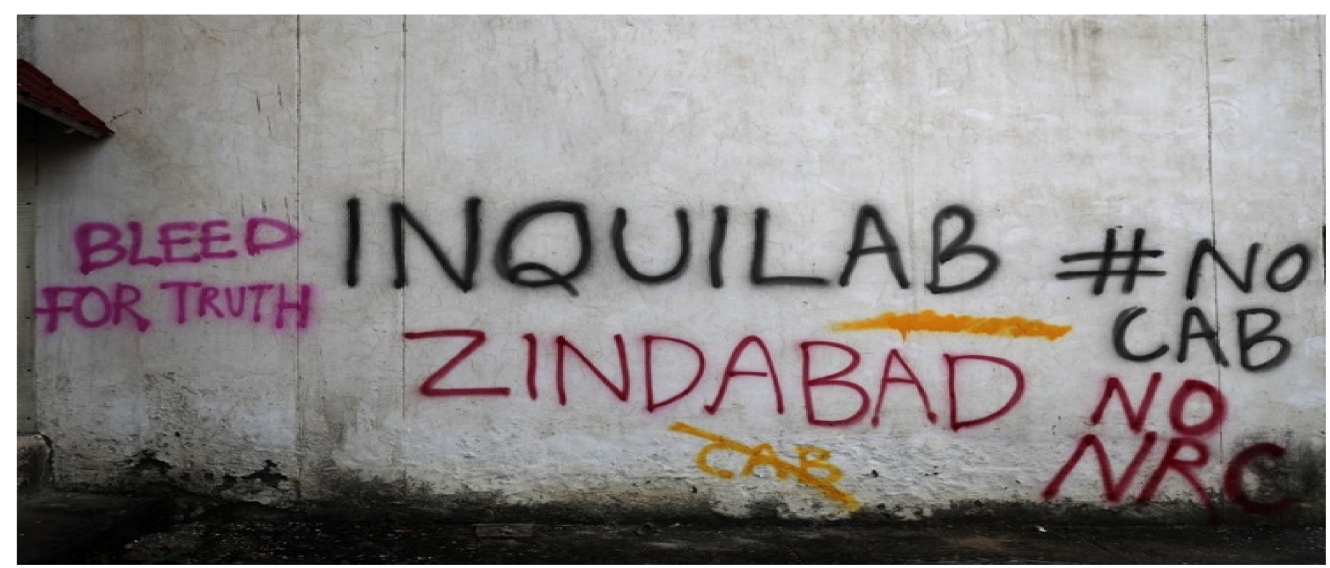

Figure 6. Graffiti inside the JMI campus shows students' discontent towards the Citizenship Amendment Act. It reads: 'Long live the revolution' (Source: [61]). 


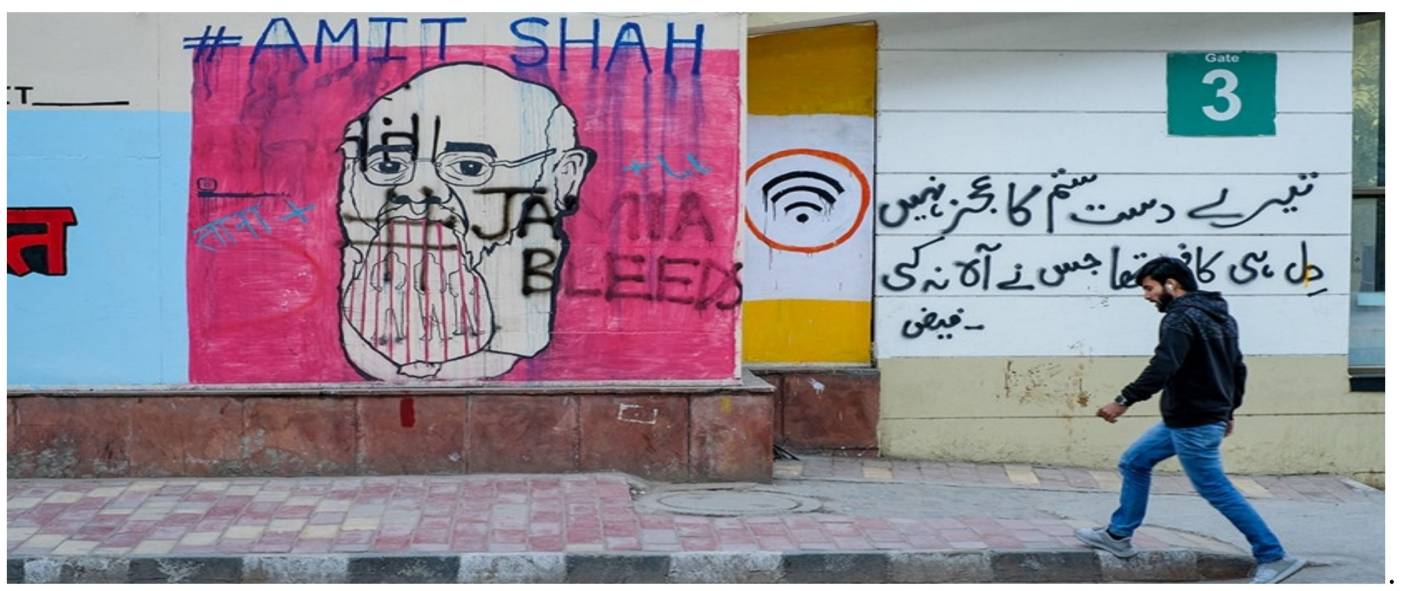

Figure 7. (Translated as 'there is no return for the pain you have given, my heart is at fault for not protesting'-Faiz.) A graffiti inside the JMI campus denouncing police brutality reads: 'There is no return for the pain you have given, my heart is at fault for not protesting'-Faiz (Source: [60]).

Students generally take their ideas from the posters that are put up by various artists on the open forum for everyone to use and mix them with couplets of revolutionary poets like Faiz Ahmed Faiz (one of the most celebrated poets of Pakistan, an avowed Marxist who won the Lenin Peace Prize for his contributions, also known for his writings against oppression in all its forms) [63]. A student said that 'Banksy is the inspiration for everyone who is associated with graffiti and street art but our creations draw inspiration from the poems as well. We are trying to come up with a Bengali typography. We already have Urdu and Hindi-it is easier for a passerby to read' [63]. Most of the students were painting graffiti for the first time but adopted this as the primary form of their protest [63].

In Lahore, Faiz's poetry and his message of 'Hum Dekhenge (we will see)', which has been used as a slogan by students from both India and Pakistan, is a message of pluralism often found as a form of street art and graffiti [63]. Particularly symbolic is how these two nations with a shared fractured past were witnessing the mushrooming of student activist movements in the form of citizenship amendment protests in India, and the student solidarity marches in Pakistan, with Faiz's revolutionary words acting as a message of solidarity, unity, and resistance [48].

JNU, JMI in India, and PU, GCU in Pakistan, in particular, became emblems of chanting students supported by beautiful graffiti that translated their words into visual art. PU has been home to multiple feminist resistance movements. In 2017, in response to gender policing activities of the Islami Jamiat Talba (IJT) (the student wing of the right-wing religious political party the Jamaat-e-Islami (JI).) within PU, such as anti-vice squads policing the dresses worn by female students and their interactions with male students, anarcho-feminist (an anti-authoritarian and anti-capitalist stance demanding equality between both genders) graffiti appeared on the walls of the campus.

Through a twist on Faiz's words concerning Azadi (independence), this graffiti (in Figure 8) translates into a call for the independence of females within the country and is symbolic of their resistance and their call for a heightened sense of belonging with the state. This is similar to the call for inquilab (independence) in neighbouring India's Jamia Islamia, where protests for freedom were being organised. Faiz's poetry and the words written across the university boundaries are an important component of the visual culture of the campuses, where the implicit messaging of the poetry contributed to notions of resistance. 


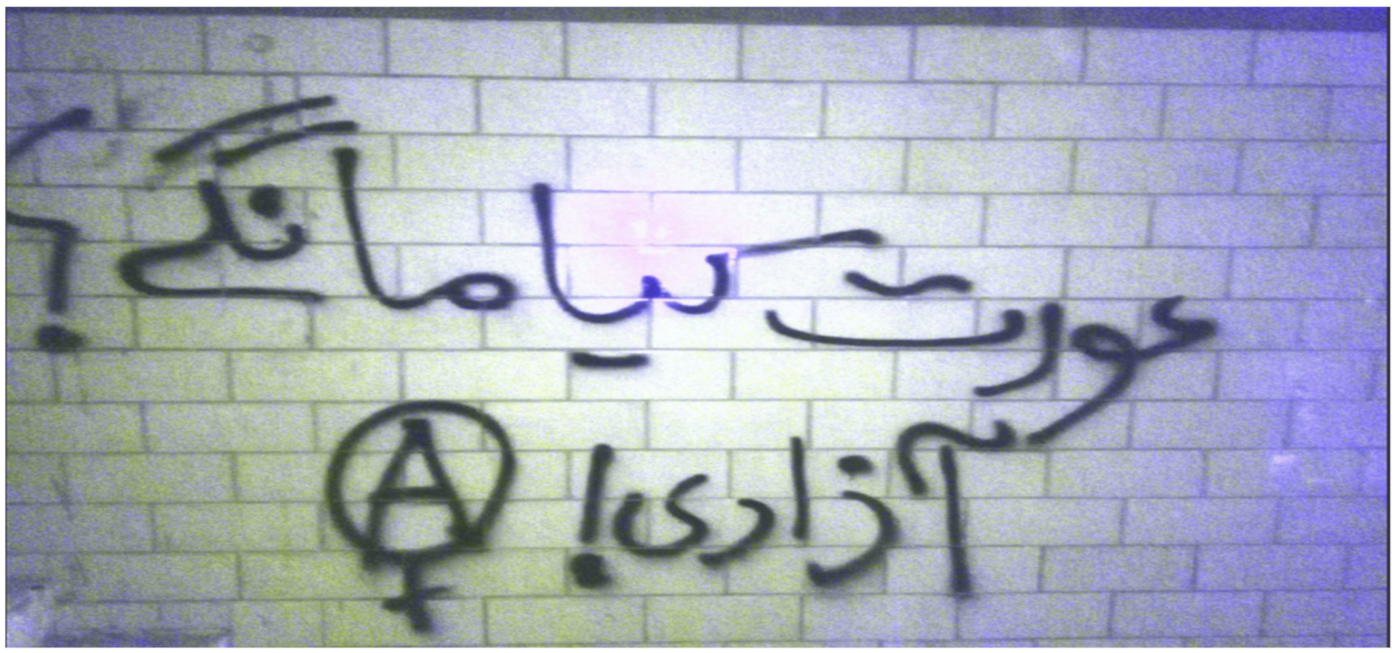

Figure 8. Graffiti inside Punjab University (Pakistan). Translation: 'What does a woman want? Azadi (Independence)' (Source: Twitter). (https:/ / twitter.com/auwn_/status /890325957776683008?ref_src=twsrc\%5Etfw\%7Ctwcamp\%5Etweetembed\% 7Ctwterm\%5E890325957776683008\%7Ctwgr\%5E\%7Ctwcon\%5Es1_\&ref_url=https\%3A\%2F\%2Fen.dailypakistan.com. pk\%2F31-Jul-2017\%2Fall-men-are-jerks-shocking-anarcha-feminist-graffiti-appears-in-punjab-university, accessed on 10 September 2021).

Interestingly, graffiti and wall art have also been employed on the walls of PU and GCU as a way of fostering national belonging towards the state, particularly in the last few years. In PU, the graffiti in the form of street art which covers the outer walls of the entire campus was commissioned by the government itself 'through an activity of Street Art on the thematic areas of Interfaith Harmony, safer charity practices, COVID-19, Resilience building, and the role of families and women in the promotion of peace' [64]. The artists were not just students from PU but also from schools, colleges, and universities across the country [64]. While addressing the media and applauding this initiative, the Deputy Commissioner of Lahore specifically mentioned how it was incredibly significant for the promotion of the national narrative-explicitly highlighting the role of the walls in fostering messages of national pride. Some photographic evidence of the graffiti is given below, in Figures 9 and 10.

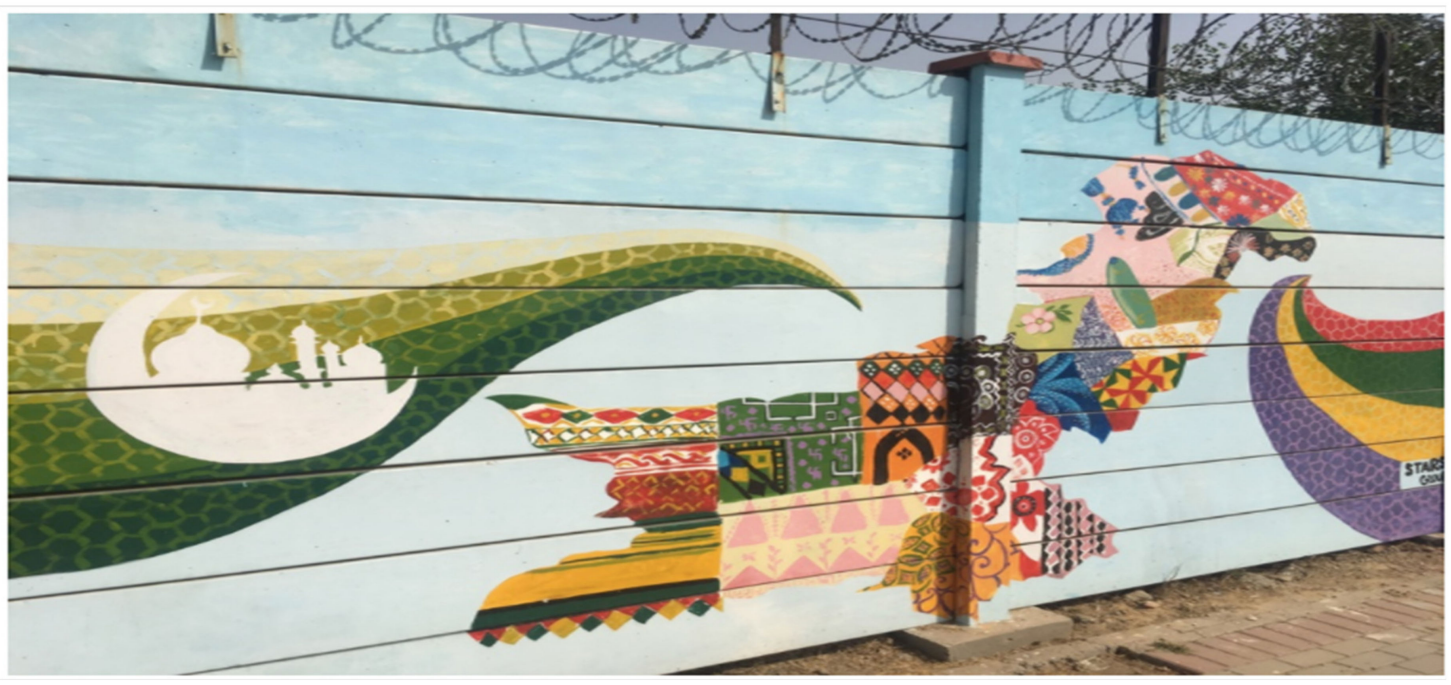

Figure 9. Wall outside Punjab University (Pakistan) showing a colourful and vibrant version of Pakistan's map and a drawing showing the crescent from Pakistan's flag, with a mosque drawn against a green background, denoting the flag's colour (Source: urbanduniya.com (http:/ / urbanduniya.com/pakistantraveller/in-photos-murals-at-the-university-of-punjab/, accessed on 10 September 2021)). 


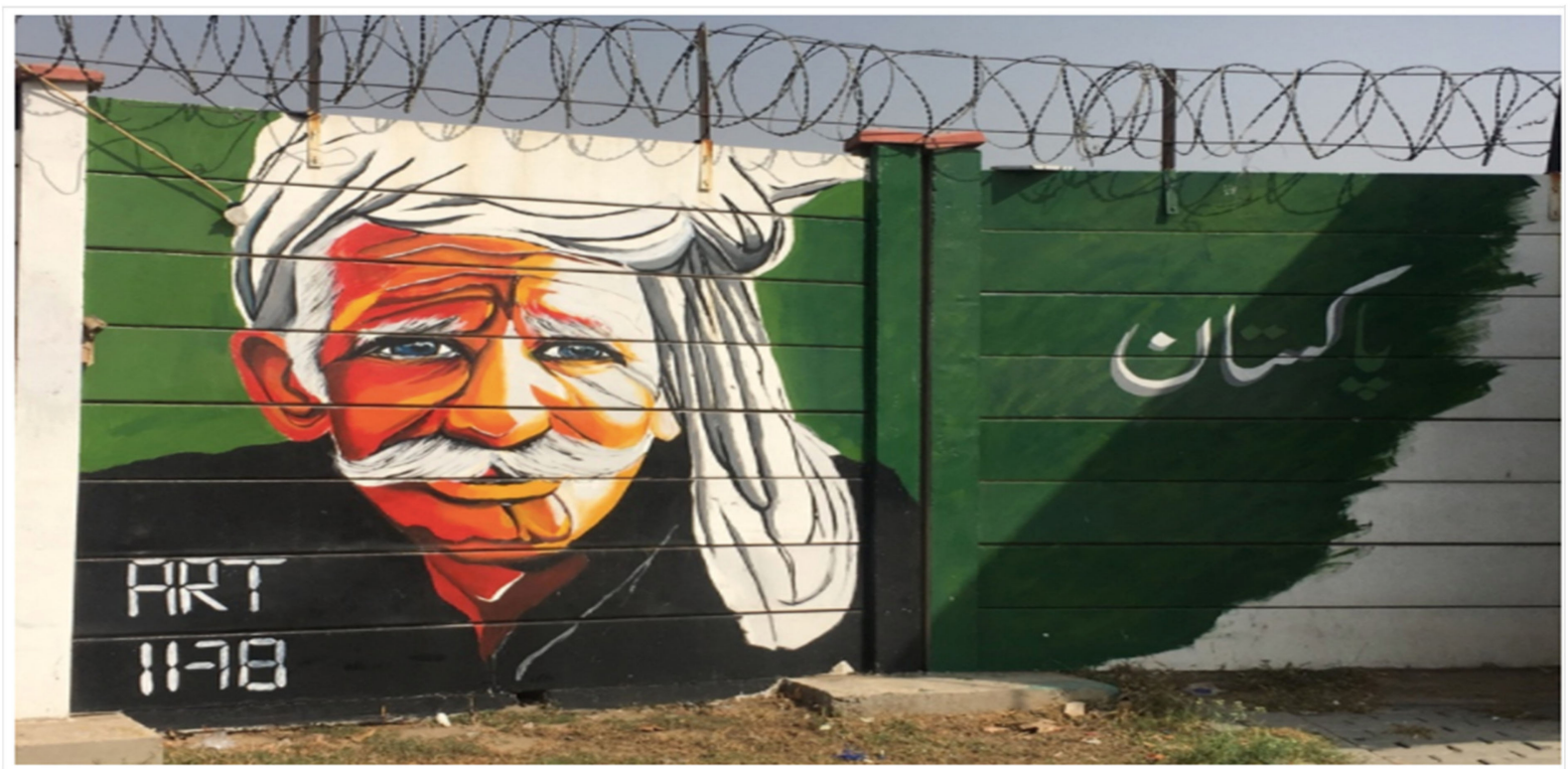

Figure 10. Wall outside Punjab University (Pakistan) showing Pakistan written in Urdu, with green paint denoting the colour of Pakistan's flag and the painted picture of a man wearing a turban (Source: urbanduniya.com, accessed on 10 September 2021).

In Figure 9, the 'green' of the Pakistani flag is coalesced with beautiful colours and a tapestry, resulting in striking street art that represents the symbolic elements of the country-its map, flag, and the crescent moon encasing a mosque. The mosque next to the map is particularly symbolic and reflective of the commingling of the Pakistani nation with Islam.

The green and white of the Pakistani flag are visible in Figure 10 as well, which is accompanied by the painting of an old man wearing a white turban (worn mostly by elderly citizens and feudal lords in Punjab, Sindh, Balochistan, and the Khyber Pakhtunkhwa provinces within the country). On the right, Pakistan is written in the national language of the country, Urdu. Here, Pakistan is synonymous with the male citizen on the left. This is also emblematic of the gender differences prevalent in the country and the preeminence of male citizens over females in all facets of society, ranging from politics to education $[65,66]$, which often fosters the construction of the male self and the female other [67]. The construction of the 'self' and the 'other' and the visual culture of universities can be seen here. These murals were therefore indicative of the larger societal culture of Pakistan and the identity of the Pakistani citizens and their belonging towards the state. How these murals and graffities are perceived by students depends on their positionalities. However, research has consistently highlighted negative attitudes towards the external 'other' through a lack of representation in textbooks and curricula in Pakistan. We believe this analysis can be extended to the spaces of schools and universities, that can potentially illustrate sameness and differences between 'in-groups' and 'out-groups'.

Whereas in India, the graffiti is mostly seen as a way of channelling student voices and their resistance against the state, in Pakistan there was evidence for both resistance against the state and the use of wall art to foster a sense of belonging to the state not dissimilar from the state's own narrative. In both countries, though, the everyday experience of the university spaces did involve the vibrant hues of the graffiti and wall art, that were linked to their association and belonging with their respective nations.

\section{Conclusions}

The themes in the last section suggest that university spaces are indeed a fundamental aspect of everyday campus life; spatiality provides a physical, social, and symbolic context of student experiences [44]. Our analysis suggests three aspects by which this occurs. First, 
this space involved the use of symbolic artefacts that orientate the university towards a particular stance of the governments and the university administrations. Second, the space is also 'conceived' as an element fostering nationalism and patriotism through the walls of heroes. Third, these spaces also leave room for student voices and resistance or conformity through graffiti and wall art.

We further suggest that spatial designs and practices are deliberately 'conceived 'to foster the image of the institution and to control students and their activities, as well as to shape the desired educational environment. This intentionality is continuously assessed against different lived contexts and the changing idealised view of higher education.

Importantly, by using the case of India and Pakistan, our analysis shows how the two countries with a shared fractured past are using the visual environment of the university spaces as an instrument for furthering national belonging and pride. In both India and Pakistan, the national flags symbolised everyday elements that would help further national pride and belonging in students. The emphasis on national pride by the vice-chancellors of both JNU in Delhi and GCU in Lahore highlight the similar and prevalent notions in both countries regarding the need to foster their national narrative in everyday campus life. Similarly, the emphasis on national and military heroes in the campuses of all four universities examined highlights, again, the emphasis on fostering the national narratives of the respective countries. These narratives might be different-with India's focusing on Nehru's secular vision and Pakistan's focusing on a unified Islamic identity, yet the shared fragmented past of the two countries is perhaps leading to a persistent effort to further the national consciousness through education. Interestingly, active student voices and their resistance movements coincided in terms of the timings in both countries, with citizenship protests in India and student solidarity marches happening around roughly the same time. What also coincided was the medium used by students in both countries to channel their voices-graffiti and wall art as well as the written words of Faiz Ahmed Faiz. What we learn by observing the spaces of the universities of both countries is the similarity in not just their infrastructure and the government's efforts towards propounding their national narratives, but also the similarity in students' voices and resistance and perhaps the way the visual culture of university spaces is potentially 'perceived' in both countries.

While our findings support the notion of the institutional use of space to ensure a favourable institutional image, we argue that it also acts as a mechanism by which university students or political parties project national values and principles and control the educational environment. The implications of space on student experience, however, also depend on contextualisation, or the ways in which students interpret the spatial designs and practices in their day-to-day lives, which is a limitation of this research and can be examined in future research by focusing on students' voices through a more ethnographic lens.

Author Contributions: Conceptualisation, Methodology and Analysis K.A. and L.N.; Editing, K.A.; Referencing, L.N. All authors have read and agreed to the published version of the manuscript.

Funding: This research received no external funding.

Institutional Review Board Statement: Not Applicable.

Informed Consent Statement: Not applicable.

Conflicts of Interest: The authors declare no conflict of interest.

\section{References}

1. Weber, M. Basic Concepts in Sociology by Max Weber; Citadel Press: New York, NY, USA, 1976.

2. Lall, M.; Vickers, E. Education as a Political Tool in Asia. Routledge: London, UK, 2008.

3. Dale, K.; Burrell, G. The Spaces of Organisation and the Organisation of Space: Power, Identity and Materiality at Work; Palgrave Macmillan: Basingstoke, UK, 2008.

4. Lall, M. India's Missed Opportunity; Ashgate: London, UK, 2001.

5. Gilmartin, D. Partition, Pakistan, and South Asian History: In Search of a Narrative. J. Asian Stud. 1998, 57, 1068-1095. [CrossRef]

6. Khan, Y. The Great Partition: The Making of India and Pakistan; New Edition; Yale University Press: New Haven, CT, USA, 2017. 
7. Jaffrelot, C. India's Democracy at 70: Toward a hindu state? J. Democr. 2017, 28, 52-63. [CrossRef]

8. Anjum, T. Saffronisation of Education in BJP-Ruled Rajasthan. Deccan Herald. 2017. Available online: https://www.deccanherald. com/content/617205/saffronisation-education-bjp-ruled-rajasthan.html (accessed on 8 August 2021).

9. Marcelo, G. India's New School Textbooks Favor Hindu Nationalist Themes, Making Minorities Uneasy. Washington Post. 2015. Available online: http://www.washingtonpost.com/national/religion/indias-new-school-textbooks-favor-hindunationalist-themes-making-minorities-uneasy/2015/03/19/30b-5dad6-ce4a-11e4-8730-4f473416e759_story.Html (accessed on 7 August 2021).

10. Traub, A. India's Dangerous New Curriculum. NY Books. 2018. Available online: https://www.nybooks.com/articles/2018/12/ 06/indias-dangerous-new-curriculum (accessed on 20 August 2021).

11. Durrani, N.; Dunne, M. Curriculum and national identity: Exploring the links between religion and nation in Pakistan. J. Curric. Stud. 2010, 42, 215-240. [CrossRef]

12. USCIRF. Connecting the Dots: Education and Religious Discrimination in Pakistan. In United States Comission on International Religious Freedom; U.S. Commission on International Religious Freedom: Washington, DC, USA, 2016.

13. Lall, M. Educate to hate: The use of education in the creation of antagonistic national identities in India and Pakistan. Comp. A J. Comp. Int. Educ. 2008, 38, 103-119. [CrossRef]

14. Saigol, R. Enemies within and enemies without: The besieged self in Pakistani textbooks. Futures 2005, 37, 1005-1035. [CrossRef]

15. Lall, M.; Saeed, T. Youth and the National Narrative: Education, Terrorism and the Security State in Pakistan; Bloomsbury Publishing: London, UK, 2019.

16. Saigol, R. The making of the Pakistani citizen: Civics education and state nationalism in Pakistan. In Constructing Modern Asian Citizenship; Routledge: New York, NY, USA, 2014. [CrossRef]

17. Lefebvre, H. The Production of Space; Basil Blackwell: Oxford, UK, 1991.

18. Apple, M. The hidden curriculum and the nature of conflict. Interchange 1971, 2, 27-40. [CrossRef]

19. Skocpol, T.; Somers, M. The Uses of Comparative History in Macrosocial Inquiry. Comp. Stud. Soc. Hist. 1980, 22, 174-197. [CrossRef]

20. Brand, S. How Buildings Learn: What Happens to Buildings after They're Built; Viking Press: New York, NY, USA, 1994.

21. Thody, A. 'Learning landscapes' as a shared vocabulary for learning spaces. In Re-Shaping Learning: A Critical Reader: The Future of Learning Spaces in Post-Compulsory Education; Boddington, A., Boys, J., Eds.; Sense Publishers: Rotterdam, The Netherlands, 2011; pp. 121-135.

22. Pauler, P.J. Disciplinary society and the myth of aesthetic justice. In Design Review: Challenging Urban Aesthetic Control; Case Sheer, B., Preiser, W.F.E., Eds.; Chapman \& Hall: London, UK, 1994; pp. 175-186.

23. Hershberger, R.G. Architecture and meaning. J. Aesthetic Educ. 1970, 4, 37-55. [CrossRef]

24. Šuvaković, M. General theory of ideology and architecture. In Architecture and Ideology; Mako, V., Roter Blagojević, M., Vukotić Lazar, M., Eds.; Cambridge Scholars Publishing: Newcastle upon Tyne, UK, 2014; pp. 2-12.

25. Blasco, M. Conceptualising curricular space in busyness education: An aesthetic approximation. Manag. Learn. 2016, 47, 117-136. [CrossRef]

26. Beyes, T.; Michels, C. The production of educational space: Heterotopia and the business university. Manag. Learn. 2011, 42, 521-536. [CrossRef]

27. Hill, L.A.; Travaglini, M.; Brandeau, G.; Stecker, E. Unlocking the slices of genius in your organisation: Leading for innovation. In Handbook of Leadership Theory and Practice: An HBS Centennial Colloquium on Advancing Leadership; Nohria, N., Khurana, R., Eds.; Harvard Business Press: Boston, MA, USA, 2010; pp. 611-656.

28. Eisner, E. The Educational Imagination, 2nd ed.; Macmillan: London, UK, 1985.

29. Martin, J. What should we do with a hidden curriculum when we find one? Curric. Inquiry 1976, 6, 135-151. [CrossRef]

30. Ward, A. Ideology, culture and the design studio. Des. Stud. 1990, 11, 10-16. [CrossRef]

31. Jackson, P. Life in Classrooms; Teachers College Press: New York, NY, USA, 1968.

32. Margolis, E. Class Pictures: Representations of race, gender and ability in a century of school photography. Vis. Sociol. 1999, 14, 7-38. [CrossRef]

33. Prosser, J. Visual methods and the visual culture of schools. Vis. Stud. 2007, 22, 13-30. [CrossRef]

34. Giroux, H.A.; Penna, A.N. Social education in the classroom: The dynamics of the hidden curriculum. Theory Res. Soc. Educ. 1979, 7, 21-42. [CrossRef]

35. Schutz, A. Collected Papers; Martinus Nijhoff: The Hague, The Netherlands, 1964.

36. Snyder, B.R. The Hidden Curriculum. Alfred A. Knopf: New York, NY, USA, 1971.

37. Gordon, D. Rules and the effectiveness of the hidden curriculum. J. Philos. Educ. 1983, 17, 207-218. [CrossRef]

38. Edwards, B. University Architecture; Spon Press: London, UK, 2000.

39. Nelson, M. Embracing the Ummah: Student Politics beyond State Power in Pakistan on JSTOR. Mod. Asian Stud. 2011, 45, 565-596. [CrossRef]

40. Anand, K.; Niaz, L. The Precarious State of Academic Freedom in Higher Education: The Case of India and Pakistan. In Research in the Social Scientific Study of Religion (RSSSR); Brill: Leiden, The Netherlands, 2020; Volume 32.

41. Braun, V.; Clarke, V. Using thematic analysis in psychology. Qual. Res. Psychol. 2006, 3, 77-101. [CrossRef] 
42. Halldorson, J. An Exploration of Tajfels Social Identity Theory and Its Application to Understanding Metis as a Social Identity. Ph.D. Thesis, University of Manitoba, Winnipeg, MB, Canada, 2009, unpublished.

43. Fairclough, N. Language and Power; Longman: London, UK, 1989.

44. Vittorini, S. Representing the Nation: Competing Symbolic Repertoires in India. Ph.D. Thesis, SOAS University of London, London, UK, 2006.

45. Ngulube, P. Qualitative data analysis and interpretation: Systematic search for meaning. In Addressing Research Challenges: Making Headway for Developing Researchers; Mathipa, E.R., Gumbo, M.T., Eds.; Mosala-MASEDI Publishers: Vorna Valley, South Africa, 2015; pp. 131-156.

46. Onyango, O.F. The Talking Walls of Rongo University College: A Linguistic Analysis of Graffiti Use at Rongo University College. Int. J. Acad. Res. Progress. Educ. Dev. 2016, 5, 1-6. [CrossRef]

47. Cohen, A. Political Anthropology: The Analysis of the Symbolism of Power Relations. Man 1969, 4, 215. [CrossRef]

48. Cohen, A. Two Dimensional Man. An Essay on the Anthropology of Power and Symbolism in Complex Societies; Routledge and Kegan Paul: London, UK, 1974.

49. Reuters. India Orders Universities to Display National Flag Amid Struggle to Contain Protests. The Guardian. 2016. Available online: https:/ / www.theguardian.com/world/2016/feb/18/india-orders-universities-to-display-national-flag-amid-struggleto-contain-protests (accessed on 8 May 2021).

50. Guha, R. Hoisting the National Flag in Central Universities Is a Great Idea. But Why at 207 Feet? The Indian Express. 2016. Available online: https:/ /indianexpress.com/article/opinion/columns/an-unpatriotic-number/ (accessed on 5 May 2021).

51. Express News Service. To 'Instil Nationalism', Smriti Irani and VCs Agree to National Flag on Campus. The Indian Express. 2016. Available online: https:/ indianexpress.com/article/india/india-news-india/hrd-ministry-national-flag-central-universities / (accessed on 10 May 2021).

52. The News. Independence Leaders Paid Homage. 2020. Available online: https://www.thenews.com.pk/print/700717 -independence-leaders-paid-homage (accessed on 20 May 2021).

53. Nair, J. New Vivekananda Statue at JNU Demands Obedience and Piety Rather than Engagement. The Indian Express. 2020. Available online: https://indianexpress.com/article/opinion/columns/vivekananda-statue-jnu-controversy-7069714/ (accessed on 16 May 2021).

54. Express Web Desk. Highlights: 'It Is Our Responsibility to Realise Swami Vivekananda's Vision for India,' Says PM Modi at JNU Event. The Indian Express. 2020. Available online: https://indianexpress.com/article/india/narendra-modi-jnu-swamivivekananda-statue-live-updates-7049144/ (accessed on 20 May 2021).

55. Paranjape, M. Listen to Modi's Speech Carefully. You'll Know Why JNU Needed a Vivekananda Statue. The Print. 2020. Available online: https://theprint.in/opinion/being-indian/listen-to-modi-speech-youll-know-why-jnu-needed-vivekananda-statue/ 543398/ (accessed on 15 May 2021).

56. India Today Web Desk. 'Wall of Heroes' Coming Soon in Indian Universities to Promote Nationalism. India Today. 2017. Available online: https:/ / www.indiatoday.in/education-today/news/story/wall-of-heroes-to-come-up-in-indian-universitiessoon-974683-2017-05-02 (accessed on 15 June 2021).

57. The Informer JNU. Politics in Posters: The Speaking Walls of JNU. The Informer JNU 2016. Available online: https:// theinformerjnu.wordpress.com/2016/03/13/politics-in-posters-the-speaking-walls-of-jnu/ (accessed on 10 September 2021).

58. Khalid, S. Walls That Speak: India's Campus Graffiti. Aljazeera. 2013. Available online: https://www.aljazeera.com/gallery/20 13/12/30/walls-that-speak-indias-campus-graffiti (accessed on 10 May 2021).

59. Asiaville Desk. Silencing the Eloquent Walls of JNU. Asiaville. 2019. Available online: https://www.asiaville.in/article/silencingthe-eloquent-walls-of-jnu-495-9949 (accessed on 19 July 2021).

60. Gayeti, S. Meet the Artists Resisting India's New Citizenship Law. ALJAZEERA. 2020. Available online: https://www.aljazeera. com/features/2020/1/29/meet-the-artists-resisting-indias-new-citizenship-law (accessed on 18 July 2021).

61. Associated Press. AP Photos: Graffiti at Indian Campus Slam Citizenship Law. Taiwan News. 2020. Available online: https: / / www.taiwannews.com.tw/en/news/3841396 (accessed on 16 July 2021).

62. Das, P. Inspired by Banksy, These Jamia Students Are Protesting with Their Graffiti on University Walls. Edexlive. 2020. Available online: https: / www.edexlive.com/news/2020/jan/17/inspired-by-banksy-these-jamia-students-are-protesting-with-theirgraffiti-on-university-walls-9922.html (accessed on 15 June 2021).

63. Ahmed, K. First Pak, Now India Has Failed the Poet Who Belongs to Both Countries. The Indian Express. 2020. Available online: https:/ indianexpress.com/article/opinion/columns/faiz-ahmed-faiz-hum-dekhenge-caa-protests-nrc-iit-kanpursecularism-islam-and-a-dying-pluralism-6198648/ (accessed on 5 July 2021).

64. Saqib, R. Extraordinary Paintings on the Boundary Wall of Punjab University. BaaghiTV English. 2020. Available online: https:/ / en.baaghitv.com/extraordinary-paintings-on-the-boundary-wall-of-punjab-university/ (accessed on 10 July 2021).

65. Zia, A.S. Faith and Feminism in Pakistan. Religious Agency or Secular Autonomy? University of Toronto: Toronto, ON, Canada, 2017.

66. Saigol, R. Knowledge and the Production of Identity: Educational Discourse in Pakistan. ProQuest Dissertations and Thesis, University of Rochester, Rochester, NY, USA, 1995.

67. Lancione, M.; Clegg, S. The lightness of management learning. Manag. Learn. 2015, 46, 280-298. [CrossRef] 